19. Васильев И.Б., Выборнов А.А., Козин Е.В. Поздненеолитическая стоянка Тентексор в Северном Прикаспии // Древние культуры Северного Прикаспия. Куйбышев: Изд-во КГПИ, 1986. С. 6-31.

20. Васильева И.Н. Технология керамики Варфоломеевской стоянки // Археология восточно-европейской степи. Вып. 9. Саратов: Изд-во СГУ, 2012. C. $5-22$.

21. Выборнов А.А., Андреев К.М., Кулькова М.А., Филиппсен Б. Радиоуглеродная хронология неолита
Волго-Камья // Уральский исторический вестник. 2018. № 3 (60). С. 66-77.

22. Выборнов А.А., Юдин А.И., К Кулькова М.А., Гослар Т., Посснерт Г., Филиппсен Б. Радиоуглеродные данные для хронологии неолита Нижнего Поволжья // Радиоуглеродная хронология эпохи неолита Восточной Европы VII-III тыс. до н.э. Смоленск: Изд-во «Свиток», 2016. С. 59-70.

Работа выполнена при поддержке гранта РФФИ № 180900040.

\title{
THE RESULTS OF THE STUDY OF THE ALGAY SITE (2019) IN THE LOWER VOLGA REGION
} (C) 2020

Vybornov Aleksandr Alekseevich, doctor of historical sciences, professor, head of Domestic History and Archeology Department

Vasilyeva Irina Nikolaevna, candidate of historical sciences, senior researcher of Research Department

Baratskov Aleksey Valerievich, candidate of historical sciences, laboratory assistant of Research Department Gilyazov Filat Faritovich, master student of Domestic History and Archeology Department Samara State University of Social Sciences and Education (Samara, Russian Federation)

Kosintsev Pavel Andreevich, candidate of biological sciences, senior researcher of Paleoecology Laboratory Institute of Plant and Animal Ecology of Ural Branch of the Russian Academy of Sciences (Yekaterinburg, Russian Federation)

Kulkova Marianna Alekseevna, candidate of geological and mineralogical sciences, associate professor of Geology and Geoecology Department

Herzen State Pedagogical University of Russia (Saint Petersburg, Russian Federation)

Kurbatova Lyudmila Aleksandrovna, master student of Domestic History and Archeology Department

Roslyakova Natalya Valeryevna, candidate of historical sciences, senior researcher of Archaeological Laboratory Samara State University of Social Sciences and Education (Samara, Russian Federation)

Yudin Aleksandr Ivanovich, doctor of historical sciences, deputy director for scientific work Research Center for the Preservation of Cultural Heritage (Saratov, Russian Federation)

Abstract. The processes of Neolithization and Eneolithization are two of the most important in the study of the human prehistory. The territory of the Lower Volga is of particular importance. In the Neolithic period, one of the oldest ceramic traditions in Eastern Europe appears. In the Eneolithic, cultures with signs of a productive economy are recorded rather early here. A further study of these issues depends on a quality source base. Monuments of the Neolithic and Eneolithic in the Volga steppe are rare. Therefore, the study of the new site Algay is very relevant. Its importance increases due to the discovery of stratigraphic data in 2019: the Eneolithic and Neolithic layers are separated by relatively sterile layers. This allows us to establish reliable periodization. Features of the lower cultural layer allowed us to trace the process of its formation. The work was interdisciplinary. The results of the technical and technological analysis of ceramics revealed the characteristic features of the Neolithic and Eneolithic. Archaeozoological definitions established the species composition of animals in the Neolithic and Eneolithic. New radiocarbon dates provide a basis for determining the exact chronological framework of the Orlovskaya and Caspian cultures in this region. Among archaeological materials, rare artifacts have been discovered that testify to social stratification already in the Neolithic period.

Keywords: Lower Volga region; stratigraphy; cultural stratum; Neolithic; Orlovskaya culture; appropriating economy; Eneolithic; Caspian culture; breeding; ceramics; ornamentation; stone tools; fauna; technical and technological analysis; radiocarbon analysis.

$* * *$

УДК 902

DOI 10.24411/2309-4370-2020-11202

Статья поступила в редакцию 20.01.2020

\section{ПОГРЕБАЛЬНАЯ ПРАКТИКА НАСЕЛЕНИЯ БАССЕЙНА КОНДЫ В МЕЗОЛИТЕ И НЕОЛИТЕ}

Клементьева Татьяна Юрьевна, научный сотрудник; специалист-археолог Институт истории и археологии УрО РАН (г. Екатеринбург, Российская Федераџия); Научно-аналитический центр проблем сохранения культурного и природного наследия «АВ КОМ - Наследие» (г. Екатеринбург, Российская Федерация)

Погодин Андрей Альбертович, заместитель генерального директора по научно-исследовательской работе Научно-аналитический иентр проблем сохранения культурного и природного наследия «АВ КОМ - Наследие» (2. Екатеринбург, Российская Федерация)

Аннотащия. В работе рассматривается погребальная практика населения эпохи камня севера Западной Сибири. Источниковая база представлена 14 комплексами. Могильники и места одиночных захоронений 
расположены на высоких боровых террасах притоков р. Конды. Погребения эпохи мезолита датируются с pубежа IX-VIII тыс. до н.э. до конца VII тыс. до н.э., неолита - с рубежа VII-VI тыс. до н.э. до середины IV тыс. до н.э. Таежное население бассейна Конды предавало умерших сородичей земле. На могильниках захоронения проводились в соответствии с рядным принципом расположения ям в границах погребального поля. Одиночные захоронения осуществлялись на территории оставленных поселков рядом с котлованами построек или внутри них. Практиковалась ингумация и кремация с последующим захоронением сожженных останков. Тела усопших в выпрямленном положении с вытянутыми вдоль туловища руками засыпали охрой, обворачивали или пеленали и помещали в могильные ямы. Особым видом в мезолите являются вертикальные погребения в округлых ямах. Кремированные останки захоранивали в могилах с охрой, сожженные кости помещали по центру ям. Превалируют одиночные погребения, реже встречены парные и ярусные. Хоронили детей и взрослых. Умерших сопровождали каменные орудия, украшения, фрагменты посуды, погребальная пища. Вещи были специально подготовлены для захоронения. Имело место особое отношение к черепам умерших. Погребальная практика таежного населения бассейна Конды имела устойчивые черты на всем протяжении каменного века.

Ключевые слова: погребальная практика; Западная Сибирь; бассейн Конды; могильники; мезолит; неолит; ингумация; кремация; вертикальные погребения; охра; пеленание; погребальный инвентарь; изделия из черепов; керамика; каменные орудия; подвески из кости; смоляные бусины-пронизки; шоушминский тип; радиоуглеродное датирование.

Проблематика погребального обряда включает широкий круг вопросов, решение которых помогает раскрыть социальные и духовные аспекты культуры древнего общества. Для периода раннего голоцена севера Западной Сибири возможность реконструкции погребальной практики являлась всегда насущной. Однако на территории Кондинского края, изобилующего древними стоянками и поселениями, погребальные памятники эпохи камня/раннего металла до недавнего времени встречались при раскопках эпизодически. Расширение объёмов спасательных работ на объектах нефтепромыслов принесло давно ожидаемые результаты: на притоках верхнего и среднего течения Конды - реках Большая Умытья, Неушья, Мулымья - были изучены новые могильники и одиночные захоронения.

Цель работы: показать контекст и интерпретационные возможности источников по погребальному обряду эпохи камня у таежных охотников Конды, обозначить особенности погребальной практики.

На сегодняшний день фонд источников по погребальной практике мезо-неолитического населения Конды включает 14 комплексов, на которых изучено 145 захоронений (рис. 1). Первые погребения эпохи камня/раннего металла открыты в бассейне Конды более 40 лет назад. Они обнаружены при изучении древних поселений и стоянок - Сатыга XVIa, Леуши IX [1], Леуши XIV [2], Геологическое III, Лева VIII, Кама II [3, с. 148-155, 157]. В последующие десятилетия одиночные погребения и/или могильники с различным числом погребений были обнаружены на береговых террасах при изучении поселений с остатками котлованов сооружений. И несмотря на компактность расположения могил, принадлежность их к одной эпохе всегда остается под вопросом. Так, на террасе правого берега р. Большая Умытья протяженностью не менее 210 м в границах поселений Большая Умытья 2 [4], Большая Умытья 8 [5; 6] и Большая Умытья 9 [7] выявлено девять захоронений, из них три одиночных, остальные расположены двумя группами по три могилы. Погребения на Большой Умытье 9 предварительно были датированы эпохой энеолита [7, с. 169]. Позже, по ${ }^{14} \mathrm{C}$-датированию останков умерших, установлено, что захоронения совершены в эпоху неолита, но в разное время (табл. 1). Некрополь с большим количеством могил исследован на памятнике Большая Умытья 100 [8; 9]. Захоронения на этой территории совершались последовательно с эпохи мезолита, в раннем и позднем неолите. Неолитические захоронения выявлены на p. Мулымья при раскопках городища Неушья 2.1 [10, c. 374] и поселения Мулымья 3 [11], но их хронология в рамках эпохи еще не уточнена. К эпохе неолита, на наш взгляд, относится и погребение на городище Большая Умытья 36 [3, с. 154-155].

Погребения эпохи мезолита по ${ }^{14} \mathrm{C}$-датированию укладываются в широкий хронологический диапазон с рубежа IX-VIII тыс. до н.э. до конца VII тыс. до н.э. (табл. 1). Несмотря на небольшое число захоронений (их всего 7), прослеживается вариативность погребальной практики. Одним из ее вариантов является захоронение черепа, которое было выявлено на поселении Леуши IX (рис. 2). Прямоугольная могильная яма размерами $0,96 \times 0,24-0,36$ м, глубиной 0,2 м была впущена в пол мезолитической землянки (сооружение 3), котлован которой впоследствии был перекрыт выкидом из мезолитического сооружения 1. Яма ориентирована Ю-С. Череп лежал на теменной доле по центру ямы, а в ее южной части локализовались угли, инвентарь отсутствовал $[1$, с. $61 ; 12$, с. $6-$ 7 , рис. $3 ; 13$, с. 28 , рис. $2: 8]$.

Три захоронения, совершенные по обряду кремации, изучены на стоянке Сатыга XVIa [1]. Сожженные останки усопших залегали в виде скоплений, мощность слоя в них составляла $0,05,0,18$ и 0,24 м. Одно из них округлое, диаметром 0,24 м, два других - овальные, размерами 1,6 × 1,1-1,2 м, вытянуты ЮС и ЮВ-С3. Усопшие были кремированы, когда на костях еще присутствовали мягкие ткани. Погребальный инвентарь включал обломки костяных вкладышевых оправ, призматические нуклеусы, орудия для обработки кости и шкур. С останками погребенных найдены сожженные кости животных.

Три погребения на могильнике Большая Умытья 100 (рис. 3) совершены в округлых ямах диаметром от 0,92 м до 1,35 м и глубиной $1,5-1,7$ м. В могилах 18 и 33 по центру ямы вертикально на толщину не менее 1 м залегала серо-красная охра. Вокруг охры и до стенок ям песчаный слой был серо-желтого цвета. В третьем погребении - могиле 35 - по центру зафиксирован также вертикально ориентированный темно-серый песок с углем толщиной не менее 1,2 м. 
Клементьева Т.Ю., Погодин А.А.

Форма ям и абрис охры указывают на вероятное помещение тела в могилу в вертикальном положении. Человеческие останки сохранились в двух могилах. На дне могилы 18 расчищен костный тлен, маркировавший останки черепа взрослого человека, под «черепом» по линии В-3 обнаружены небольшие фрагменты параллельно расположенных длинных костей. Близ этих костей в слое охры найден концевой скребок на пластине с ретушированным продольным краем (рис. 4: 12). Изделие размерами $51 \times 22 \times 10$ мм из- готовлено из серо-зеленого кремня. Обработка краев выполнена ударом. Орудие использовалось для обработки шкуры, оба конца инструмента изношены (определение выполнено к.и.н. Е.Ю. Гирей). Помимо этого, имеются следы общего износа от длительного ношения и следы заглаженности от рукояти. Ретушь по продольному краю «свежая». В могиле 33 расчищен фрагмент большеберцовой кости взрослого человека (антропологические определения выполнены к.и.н. Д.И. Ражевым и Е.О. Святовой).

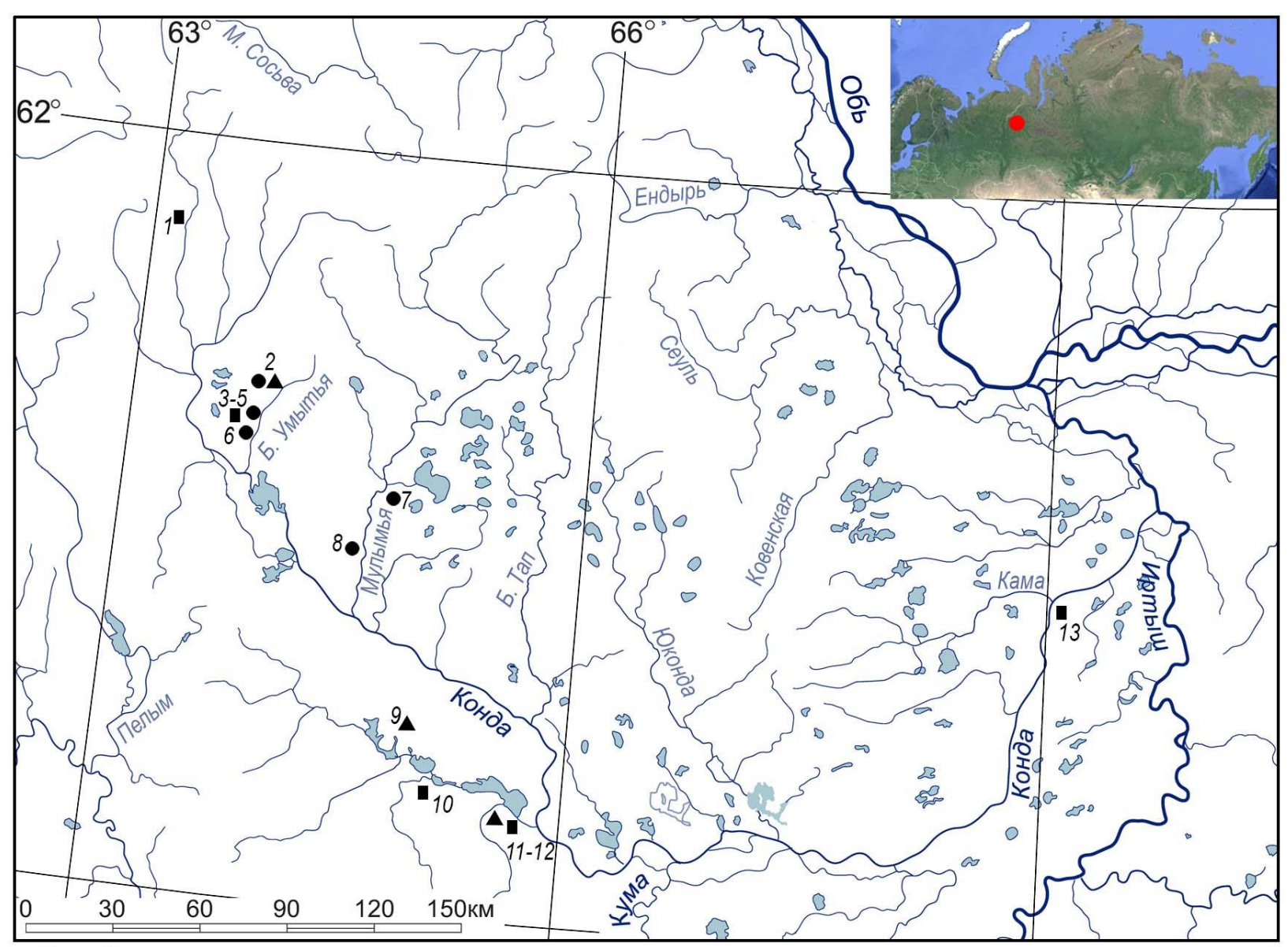

Погребальные памятники: А - эпохи мезолита; - неолита; п - раннего металла

Рисунок 1 - Погребальные памятники эпохи мезолита - раннего металла в бассейне Конды:

1 - Геологическое III; 2 - Большая Умытья 100; 3-5- Большая Умытья 2, 8, 9; 6- Большая Умытья 36;

7- Мулымья 3; 8- Неушья 2.1; 9-Сатыга XVIa; 10- Лева VIII; 11, 12- Леуши IX, XIV; 13- Kaмa II

$A$

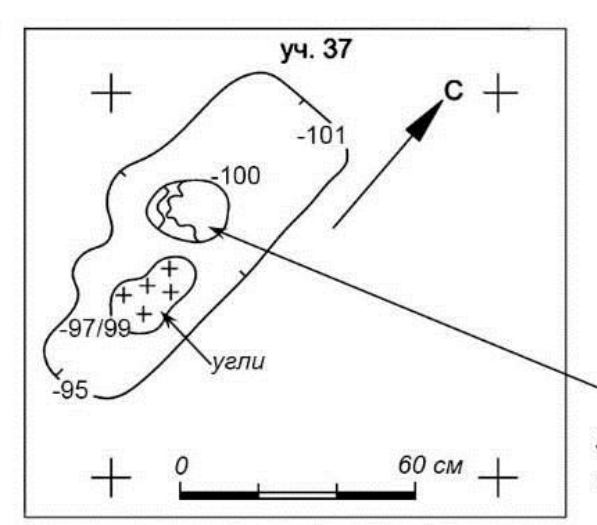

Б

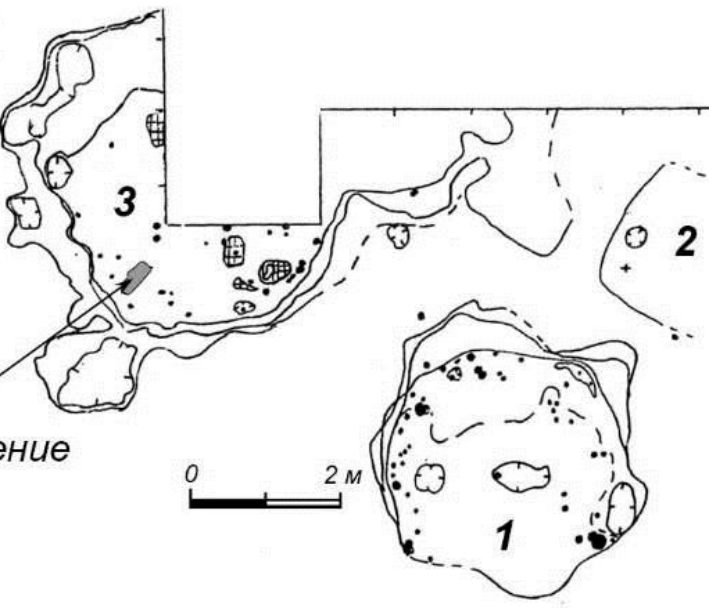

Рисунок 2 - Поселение Леуши IX.

$A$ - план погребения, 5 - план мезолитического поселка [по: 12 , с. $6-7$, рис. $3 ; 13$, с. 28 , рис. $2:$ : $]$ 
Клементьева Т.Ю., Погодин А.А.

Погребальная практика населения бассейна Конды в мезолите и неолите

Исторические науки и археология

Таблица 1 - Радиоуглеродные даты

\begin{tabular}{|c|c|c|c|c|c|}
\hline \multirow{2}{*}{ Памятник } & \multirow{2}{*}{ Контекст, материал } & \multirow{2}{*}{ Индекс лаборатории } & \multirow{2}{*}{$\mathrm{BP}$} & \multicolumn{2}{|c|}{$\mathrm{BC}^{*}$} \\
\hline & & & & $1 \sigma(68,2 \%)$ & $2 \sigma(95,4 \%)$ \\
\hline \multirow{4}{*}{ Леуши IX } & Сооружение 1 , уголь & ЛЕ-2247 & $7560 \pm 80$ & $6491-6268$ & $6588-6244$ \\
\hline & Сооружение 3, уголь & ЛЕ-2249 & $7430 \pm 80$ & $6391-6234$ & $6441-6099$ \\
\hline & Сооружение 1, уголь & ЛЕ-2244 & $7240 \pm 80$ & $6211-6034$ & $6336-5928$ \\
\hline & Сооружение 1, уголь & ЛЕ-2243 & $7030 \pm 80$ & $5998-5841$ & $6033-5741$ \\
\hline \multirow{7}{*}{$\begin{array}{l}\text { Большая } \\
\text { Умытья } 100\end{array}$} & Могила 33, уголь & $\mathrm{SPb}-1115$ & $8600 \pm 150$ & $7937-7510$ & $8205-7352$ \\
\hline & Могила 35, уголь & $\mathrm{SPb}-1111$ & $8123 \pm 150$ & $7341-6830$ & $7488-6684$ \\
\hline & Яма 54, уголь & $\mathrm{Ki}-17973$ & $7090 \pm 60$ & $6021-5904$ & $6066-5843$ \\
\hline & Яма 237, уголь & $\mathrm{SPb}-1110$ & $6079 \pm 70$ & $5201-4851$ & $5212-4810$ \\
\hline & Могила 22, уголь & $\mathrm{SPb}-1428$ & $6050 \pm 80$ & $5056-4836$ & $5212-4782$ \\
\hline & Сооружение 14, уголь & $\mathrm{Ki}-17968$ & $5310 \pm 60$ & $4232-3819$ & 4226-3797 \\
\hline & Сооружение 14, уголь & $\mathrm{Ki}-17969$ & $5170 \pm 60$ & 4046-3819 & 4229-3797 \\
\hline \multirow{3}{*}{$\begin{array}{l}\text { Большая } \\
\text { Умытья } 9\end{array}$} & Погребение 3, кость & AMS 1793/59114 & $6770 \pm 40$ & $5707-5641$ & $5726-5626$ \\
\hline & Погребение 1, череп & AMS 1793/ 59113 & $5505 \pm 35$ & $4441-4329$ & $4449-4268$ \\
\hline & Погребение 2, уголь & $\mathrm{SPb}-2545$ & $4454 \pm 45$ & $3327-3025$ & $3341-2936$ \\
\hline
\end{tabular}

Примечание. * калибровка проведена в программе OxCal v4.3.2; r:5; IntCal13.

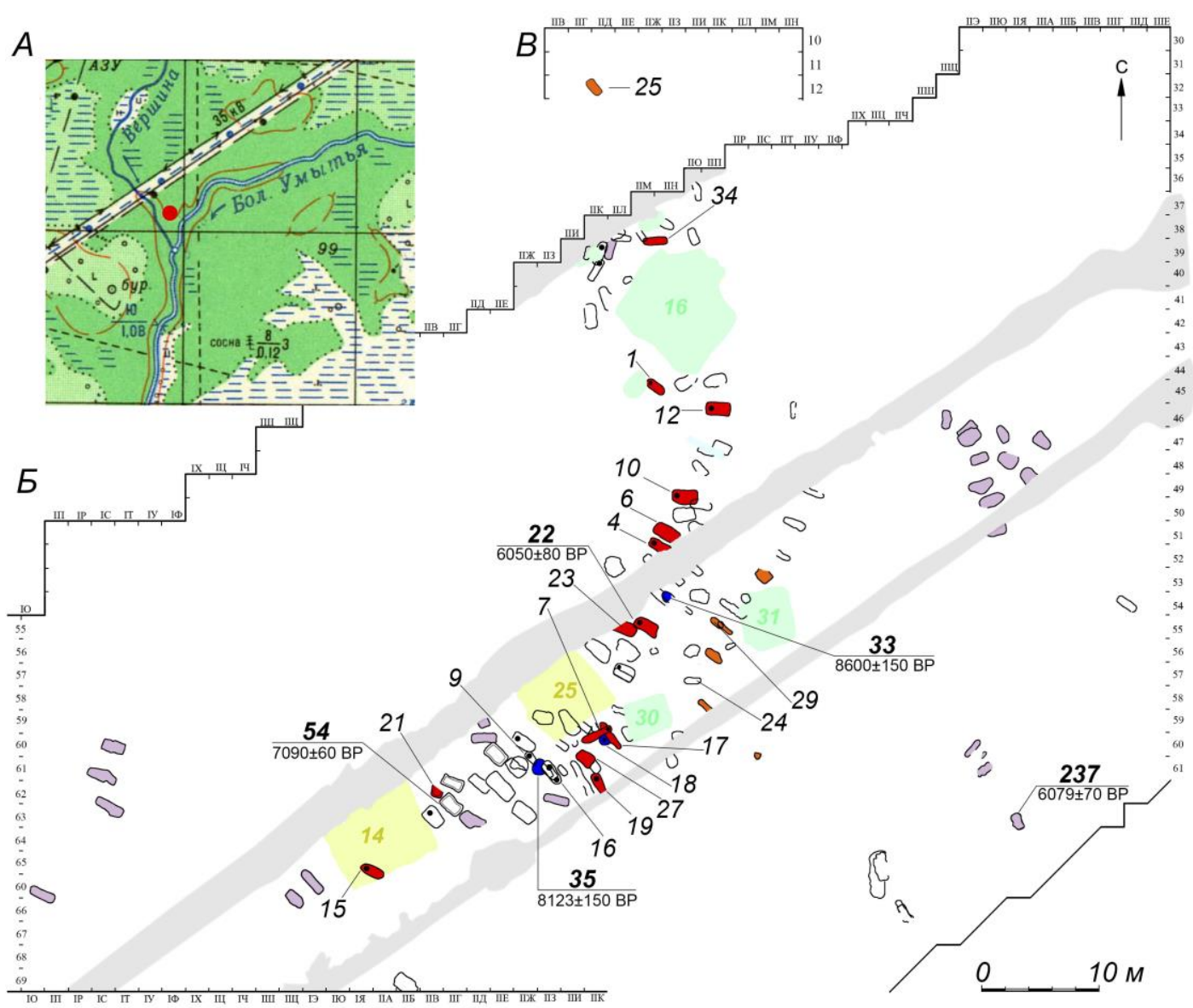

Условные обозначения: $\bullet-1, \oslash-2, \square-3, \odot-4, \diamond-5, \varpi-6, \odot-7, \frac{54}{7090+60 \mathrm{BP}}-8,30-9,14-10, \square-11$

Рисунок 3 - Могильник Большая Умытья 100:

$A$ - схема расположения, 5 - план раскопа: могилы эпохи мезолита (1) и неолита (2-7):

2-5-с охрой, 6- без охры, 3-с канавками, 4-с инвентарем, 5-с кремацией, 6- положение

головы погребенного в могилах с ингумацией; 8 - номера могил и ${ }^{14}$ С-даты; 9-11- разрушения могильника котлованами сооружений раннего (9) и позднего (10) неолита, современными траншеями (11); $B-$ могила 25

Погребения раннего неолита датируются рубежом VII-VI тыс. до н.э. - серединой V тыс. до н.э. (табл. 1). Они выявлены на трех памятниках - 118 захоронений на могильнике Большая Умытья 100 и по одному погребению на поселениях Большая Умытья 8 и Большая Умытья 9.

Погребение 3 на Большой Умытье 9 совершено в овальной яме размерами $0,9 \times 0,4$ м и глубиной 0,3 м, ориентированной С-Ю. В ее южной части в слое ро- зовой охры лежал фрагмент черепа, принадлежавший мужчине 16-26 лет. Погребальный инвентарь отсутствовал [7, с. 173].

Погребение (яма 10) на Большой Умытье 8 совершено в прямоугольной яме в 45 м от бровки речной террасы. Могила ориентирована ЮЮВ-СС3, ее размеры $2,30 \times 1,75$ м, глубина 0,75 м [6, с. 45-48]. На дне могилы в линзе красной охры найден зуб человека и фрагменты от сосудов умытьинского типа. 


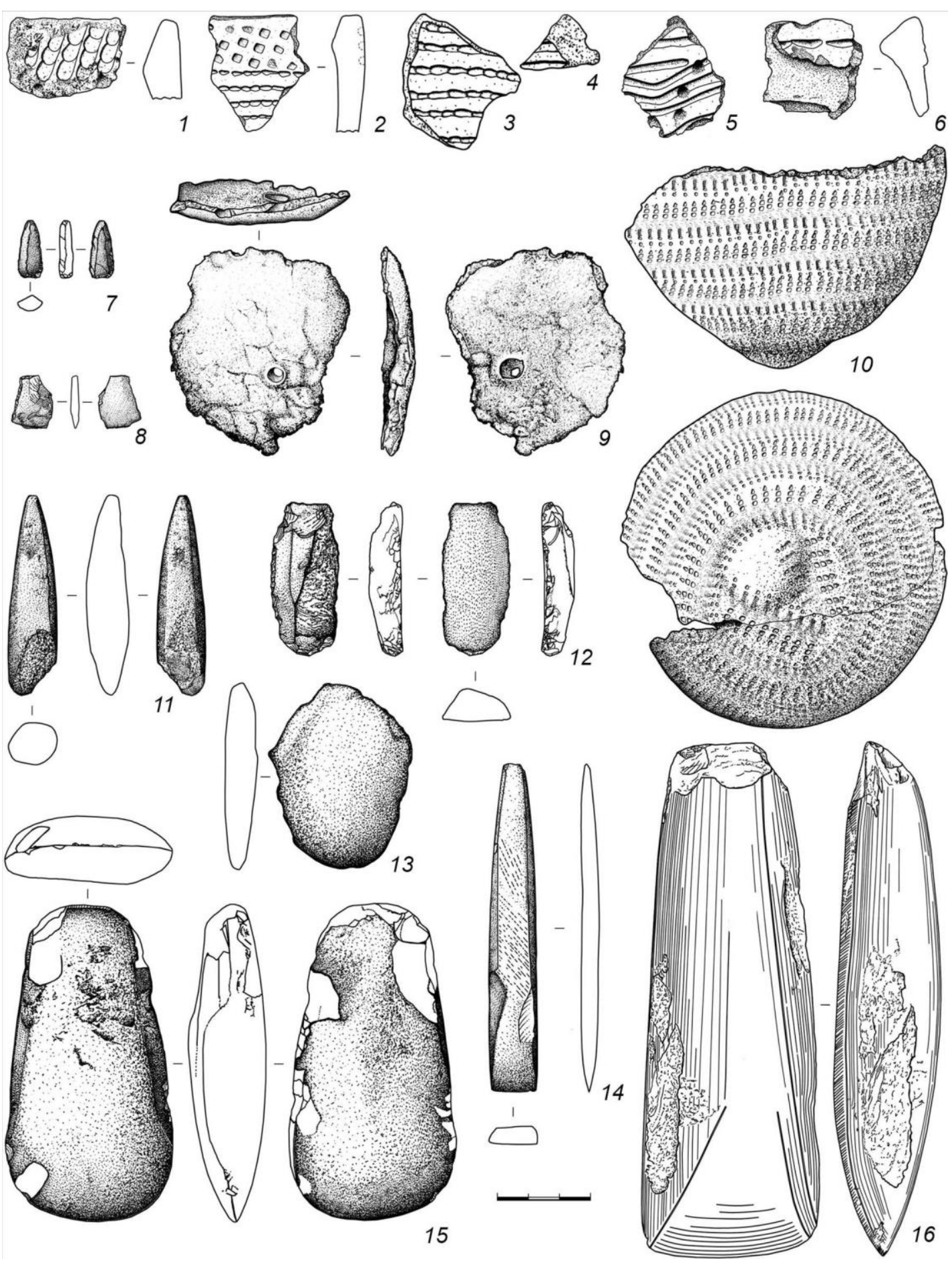

Рисунок 4 - Могильник Большая Умытья 100.

Погребальный инвентарь: 1, 2-мог. 19; 3, 4-мог. 23; 5 -мог. 27; 6, 7-мог. 4; 8-мог. 17; 9 -мог. 12; 10 -мог. 22; 11 -мог. 34; 12 -мог. 18; 13, 15 -мог. $15 ; 14$-мог. $21 ; 16$-мог. 10. 1-6, 10- керамика, 7, 8, 11-16- изделия из камня: 7, 11- острия; 8 -отщеп с ретушью; 12 -скребок; 14 - стамеска; 13, 15, 16 - тесла; 9- изделие из человеческого черепа

На Большой Умытье 100 «ядром» ранненеолитического могильника являются не менее четырех длинных рядов погребений, расположенных параллельно друг другу и ориентированных Ю3-СВ (рис. 3). Количество могил в этих рядах - от 8 до 21. На востоке и западе в 12-20 м от «ядра» могильника располагались обособленные локации с рядной планировкой, от 3 до 6 ям в ряду. Форма ям прямоугольная (76\% - от ранненеолитических захоронений), овальная (21\%) и сигаровидная (3\%). Могилы ориентированы С3-ЮВ (56\%), Ю3-СВ (15\%) и 3-В (10\%). Две трети ям имеют длину от 1,56 м до 2,50 м и глубину от 0,15 м до 1,40 м. Стенки ям вертикальные или слегка наклонные, плавно переходящие к чашевидному (в поперечном сечении) дну. В 4-х ямах по периметру ниже дна выявлены канавки. Их ширина 0,15-0,20 м, глубина 0,05-0,18 м.

В 76\% могил присутствовала бордовая или красная охра. Абрис охры в плане всегда был четким, в разрезе линза имела очертания уплощенного овала. Обычно слой охры заканчивался на глубине $0,1-$ 0,2 м выше дна могилы. Обратим внимание, что почвы севера Западной Сибири характеризуются высоким промывным режимом, и, несмотря на эту осо- 
бенность, охра не расплылась по яме, а сохранила четкие очертания. Этот факт может указывать на помещение тела, засыпанного охрой, в мягкие пелены. Концентрация охры увеличивалась от ног погребенного к голове. Как минимум в пяти могилах охра фиксировалась на двух/трех уровнях в верхнем или среднем заполнении ямы. Не исключено, что таким образом, при отсутствии антропологических останков, могут быть маркированы ярусные захоронения. Примечательно, что погребения без охры располагались на западной, восточной и южной периферии могильного поля. В центральном массиве зафиксировано лишь 9 погребений без охры. Отметим, что верхнее и среднее заполнение ям содержало уголь разной степени насыщенности. Включения мелких угольков отмечены и на уровне залегания усопшего, но признаки высокотемпературного воздействия на костях отсутствуют.

Останки усопших сохранились плохо: в 29 погребениях обнаружен костный тлен, мелкие фрагменты костей и эмаль зубов. Практиковалось два обряда ингумация и кремация. При ингумации тела умерших укладывали в выпрямленном положении с вытянутыми вдоль корпуса руками и выпрямленными ногами, лицом вверх или вниз, головой на С3 (60\%), $\mathrm{CB}(13 \%)$ и 3 (13\%). Преобладают одиночные захоронения. Достоверно к парным относится могила 9; в ней два человеческих черепа (пол не установлен) лежали рядом на одном уровне в слое бордовой охры. Могила 16 ярусная - между дном ямы и ярусом 0,4 м, в ней обнаружены останки двух умерших, один из них 20-30 лет. Тела были уложены противоположно друг другу, головами на С3 и ЮВ.

Кости с признаками высокотемпературного воздействия обнаружены в семи могилах. Видимо, таких захоронений было больше. Сожженные кости найдены в переотложенных грунтах руинированных построек последующих эпох. Шесть кремированных захоронений находились в южной части могильника, еще одно (мог. 25) - на его северной территории. К сожалению, пространство между основным массивом могил и его северной периферией (?) разрушено землеройным карьером. Захоронения с кремациями обладали общими признаками с погребениями по обряду трупоположения. Они совершены в прямоугольных или овальных ямах, ориентированы С3ЮВ. В заполнении могил присутствовала охра, в которой, преимущественно по центру ямы, залегали кремированные останки. Сжигание тел осуществлялось вне территории могильника на открытом пламени при температуре $400-1000^{\circ} \mathrm{C}$. Тело покойника из могилы 25 было сожжено вскоре после наступления смерти. В других случаях сжигались скелетированные останки. В двух погребениях (мог. 16В и мог. 29) сожженные останки и кости без термического воздействия залегали совместно.

На могильнике хоронили взрослых и детей. 14 погребенных умерли после достижения 16-18 лет. В могиле 24 был захоронен семилетний ребенок. Зуб ребенка, умершего в возрасте 5-12 лет, найден в сооружении 14 эпохи позднего неолита; при его строительстве были разрушены могилы на юго-западной части некрополя. Детские останки (до 7 лет) определены и среди кремированных костей разрушенных погребений. Пол определен у 6 погребенных - 3 женщины и 3 мужчины. По мнению Д.И. Ражева, одонтологические признаки - пятибугорковый второй нижний моляр - указывают на присутствие у индивида, захороненного в верхнем ярусе могилы 16 , генов «восточно- го» расового ствола (монголоидов). Состояние зубной системы погребенного хорошее, без заболеваний или маркеров физиологического стресса (болезнь, голод), перенесенных в детстве. Погребенный в могиле 28 взрослый индивид перенес при жизни перелом костей.

Умерших сопровождали каменные орудия, украшения и фрагменты посуды (рис. 4). Такие вещи найдены в 14 погребениях (12\%), а в трех могилах еще и кости животных. Просматривается закономерность в расположении вещей. В область головы уложены шлифованные тесла (мог. 10, 15), строгальный нож, пренуклеус и бусины-пронизки (мог. 1), сколпластина с бобрового резца (мог. 12); у пояса - отщеп с краевой ретушью (мог. 17), наконечник стрелы (мог. 1), острие (мог. 4), сколы со шлифованных изделий; в ногах - нижняя половина глиняного сосуда (мог. 22). Посуда очень фрагментарна, и, видимо, это сделано намеренно; мелкие черепки встречаются как на дне могил, так и в грунтах заполнения.

Шлифованные инструменты изготовлены из серого-зеленого сланца. Тесла из могил 10 и 15 (рис. 4: $13,15,16$ ) и острие из могилы 34 (рис. $4: 11$ ) оформлены оббивкой и продольной шлифовкой, стамеска из могилы 21 (рис. 4: 14) - грубой диагональной шлифовкой. Тесла массивные трапециевидной в плане формы, в профиле - трапециевидной и линзовидной. Особенностью орудий из могилы 15 является наличие неглубоких продольных желобков на одной из поверхностей. На теслах есть следы утилитарного износа и следы подновления, т.е. с умершими клали использовавшиеся ранее, но целые, и даже заново заточенные инструменты. Следы подновления имеются на ретушированном наконечнике и пренуклеусе из могилы 1 (рис. 5: 9, 11). В могилах 22, 23, 25 и 16 обнаружены мелкие отщепы, в могилах 6, 5 и 11 - сколы-чешуйки, в могиле 12 - обломок шлифованного изделия. Отнесение чешуек-сколов к погребальному инвентарю сомнительно. Не исключено, что попадание их в яму произошло при возведении деревянных конструкций могилы. Так, на сколе-чешуйке из могилы 6 имеются следы, возникшей во время работы сланцевым теслом.

Украшений немного, но каждое из них индивидуально. У молодого человека 16-25 лет (мог. 1) в области груди найдено ожерелье из смоляных цилиндрических бусин-пронизок (рис. 5: B). Обнаруженная в могиле 12 скол-пластина бобрового резца могла являться деталью украшения костюма. Также из могилы 12 происходит фрагмент черепа с двумя отверстиями (рис. 4: 9). Он лежал в области головы усопшего и с ним не связан. Сверление встреченное, отверстия биконические.

В восьми погребениях обнаружены обломки глиняной посуды. Фрагменты толстостенных сосудов шоушминского типа, украшенных в прочерченной и накольчатой технике, лежали в могилах 4, 19, 23 и 27 (рис. 4: 1-6). В могилах 1, 3 и 12 обнаружены мелкие фрагменты сосудов умытьинского типа, однако их намеренное положение с погребенным не бесспорно (ямы находились вблизи неолитического умытьинского сооружения 16). В могиле 22 в ногах погребенного обнаружена нижняя половина округлодонного сосуда. На его дне оформлен шиповидный выступ, поверхность покрыта плотным шагающегребенчатым орнаментом (рис. 4: 10). Эти признаки встречаются на посуде умытьинского типа, хотя и не являются базовыми. Помимо этого, на дневной поверхности могильника между погребениями встречены фрагменты толстостенной посуды, часть которой может быть отнесена к шоушминскому типу. 


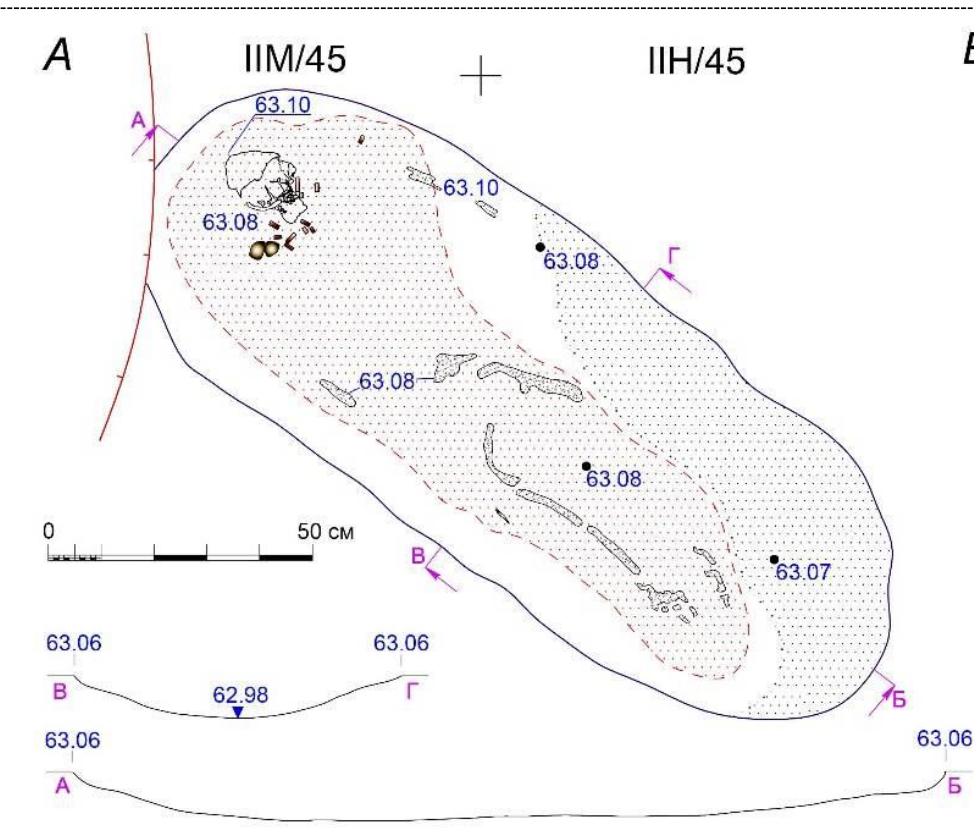

Условные обозначения:

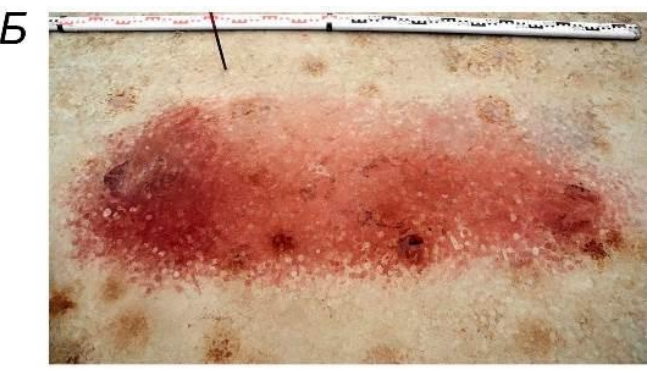

1

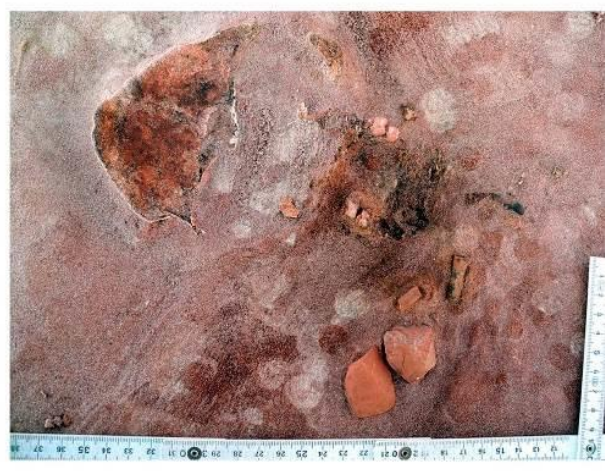

$-1, \div-2, \quad-3, \ldots-4, \diamond-5,-6, \infty-7, \vee-8, \bullet-9,63.06-10$

$B$
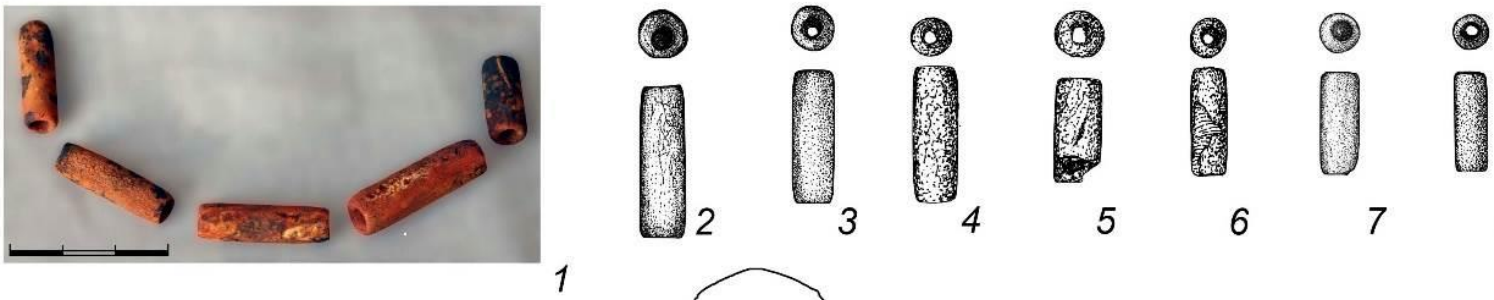

6

7
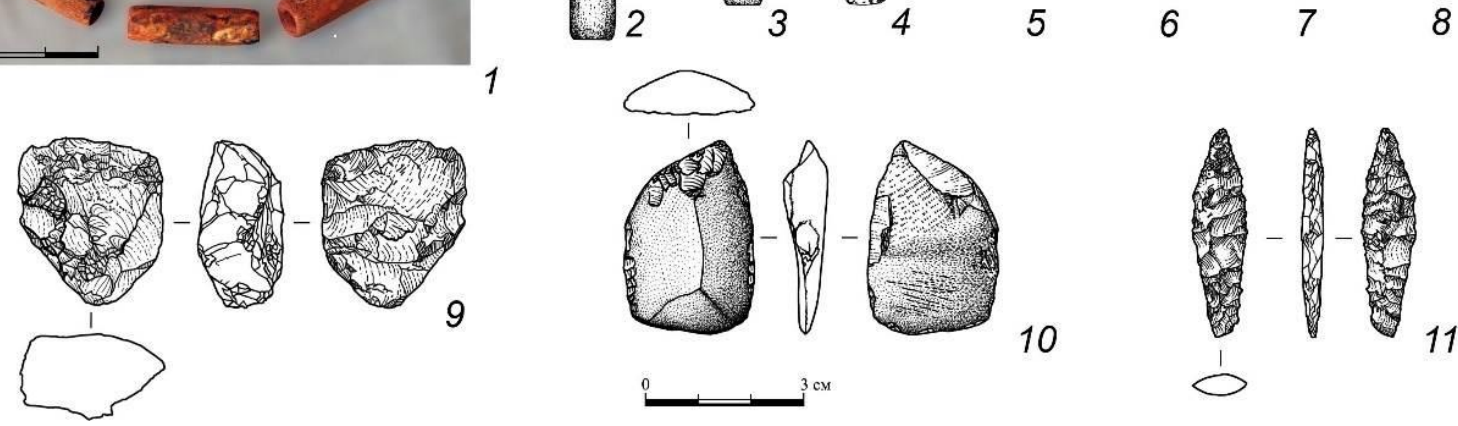

10

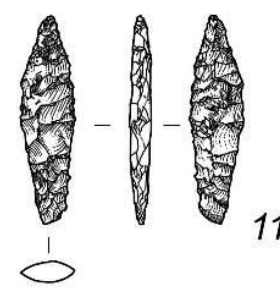

Рисунок 5 - Могильник Большая Умытья 100, могила 1.

$A$ - план и профили разрезов могилы: 1 -очертания могилы на уровне 63,06 м,

2 -очертания внешней ямы сооружения 16, 3- красный охристый песок,

4 -светло-серый песок, 5 -костный тлен, 6-пронизки, 7-пренуклеус и струг, 8 - наконечник, 9-фрагмент керамики, 10 -высотные отметки;

5 - могила 1 на уровне фиксации 63,10-63,06 м, вид с Ю3 (1), кости черепа и предметы in situ вид с Ю3 (2); $B$ - пронизки из смолы (1-8), изделия из камня - пренуклеус (9), струг (10), наконечник (11)

Захоронения позднего неолита совершены в хронологическом интервале конец V тыс. до н.э. - первая половина IV тыс. до н.э. (табл. 1).

Погребение 1 на Большой Умытье 9 устроено в прямоугольной яме, ориентированной СС3-ЮЮВ. Останки принадлежат мужчине 16-26 лет; кости залегали на дне ямы в розовой охре. С усопшим в могилу положены два отщепа без ретуши и отщеп с краевой ретушью из халцедона, скол со шлифованного орудия, шлифованное тесло и сланцевое кольцо. Отщепы и тесло лежали по центру ямы на дне, каменное кольцо - в северной половине у западной стенки [7, с. 169].

К позднему неолиту на Большой Умытье 100 относится могила 7. Могильная яма выкопана в 1,2 м от южной стены котлована поздненеолитического сооружения 25. Она прорезала на 0,1 м верхнюю часть могилы 17 раннего неолита. Могила 7 по форме удлиненно-овальная, размерами $2,43 \times 0,55 \mathrm{M}$, глубиной 0,47 м, ориентирована ВСВ-ЮЗЮ. Северная половина ямы маркировалась красной охрой, а южная - серым песком. На дне ямы, у северовосточного края, расчищена часть черепной коробки мужчины 35-60 лет, в средней части ямы - костный тлен посткраниального скелета, лежавшего в анатомическом порядке. Края свода черепа, вероятно, были специально подработаны и выровнены таким образом, чтобы череп представлял собой подобие «чаши». Внутри черепа находилась 21 подвеска, три заготовки и четырехгранное костяное изделие (рис. 6). Подвески изготовлены из кости лося (определение к.б.н. П.А. Косинцева), их форма каплевидная в плане, 
Клементьева Т.Ю., Погодин А.А.

Погребальная практика населения бассейна Конды в мезолите и неолите

Исторические науки и археология

в поперечном сечении - «грушевидная» или каплевидная. На зауженном конце изделий встречным сверлением образованы отверстия для подвешивания диаметром 0,2 см (рис. 6: Д: 1-7, 9-14). Готовые изделия тщательно отполированы (рис. 6: Б: 1-3, 5-7); заготовки покрыты негативами срезов (рис. 6: $5: 4,8$, 9). В области пояса, с правой стороны от погребенного, был положен каменный гребенчатый штамп (рис. 6: 17). Гребенчатым штампом из этого погребения была декорирована посуда из сооружения 25 поселения Большая Умытья 100 [14, с. 40-41]. Костяные подвески каплевидной формы помимо могилы 7 обнаружены в поздненеолитическом сооружении 14. Эта постройка существовала на рубеже V-IV тыс. до н.э. (табл. 1). На наш взгляд, захоронение в могиле 7 совершено уже после того, как поселок был оставлен.

A

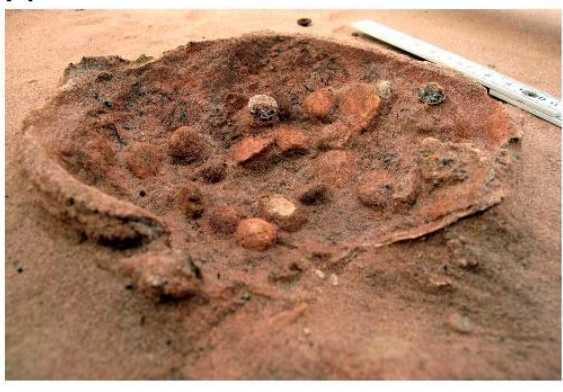

$B$

Условные обозначения:

$-1,--2, \quad-3, \ldots-4$,

- $-5,-6,62.16-7$,

5
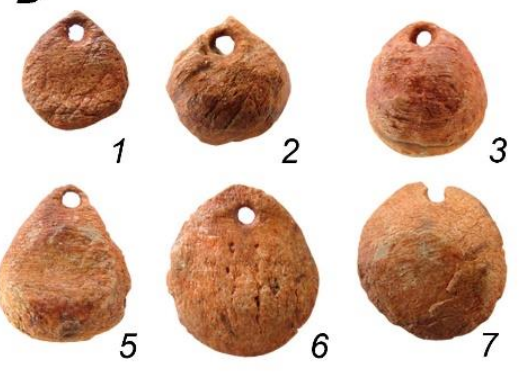

.

4

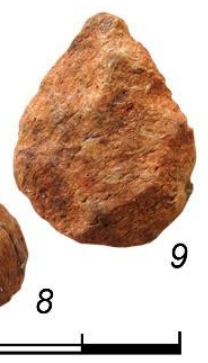

62.13

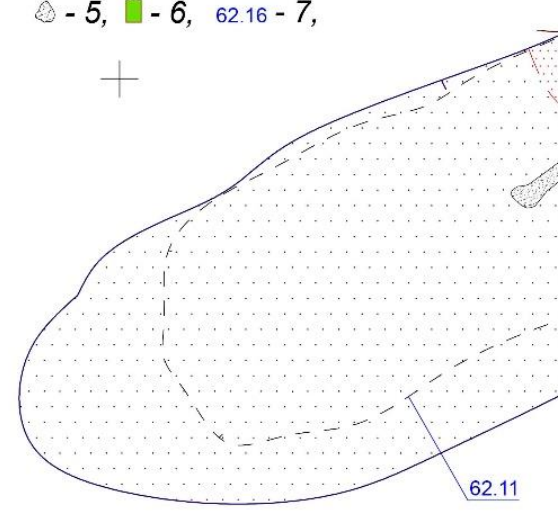

म
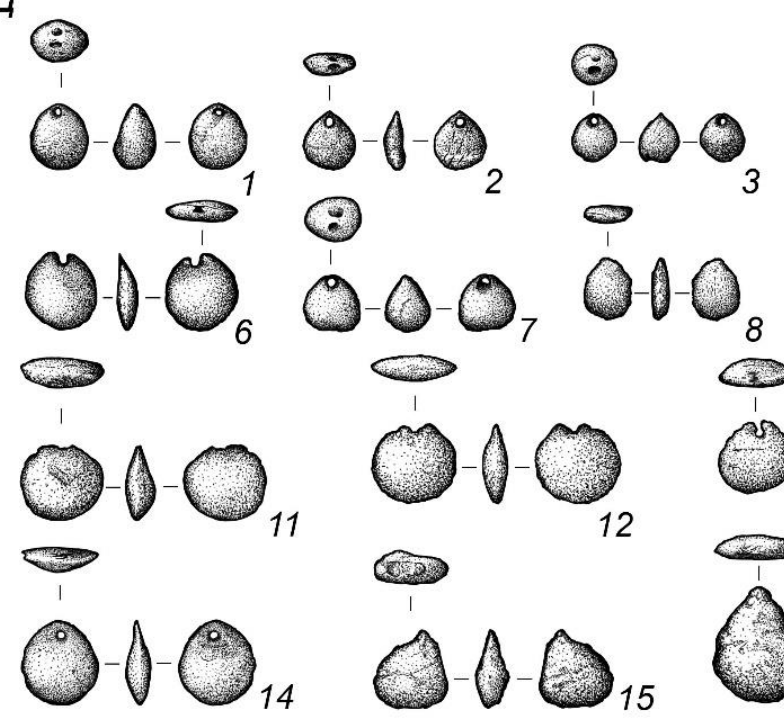

\section{3}
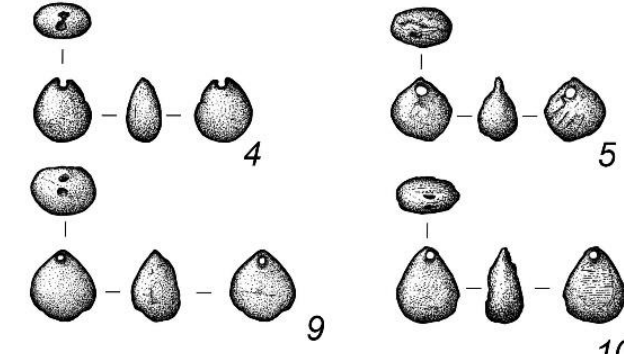

3

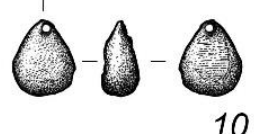

10
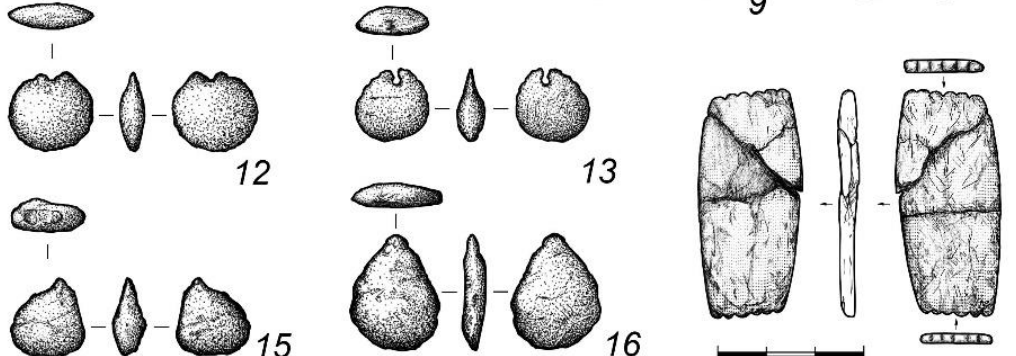

16

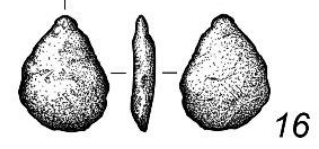

7

Рисунок 6 - Могильник Большая Умытья 100, могила 7.

$A$ - череп с подвесками in situ на уровне 62,11-61,06 м (вид с юга);

Б- подвески $(1-3,5-7)$ и заготовки $(4,8,9)$;

$B$ - план и профиль разреза могилы: 1, 2- очертания могилы на уровне 62,16 м и 62,11 м,

3 -желто-серый песок с красной охрой, 4- серый песок, 5- костный тлен, 6- гребенчатый штамп,

7- высотные отметки; Г- схема расположения подвесок и заготовок внутри черепа;

Д- костяные подвески $(1-7,9-14)$ и заготовки $(8,15,16)$, каменный гребенчатый штамп (17) 
На первый взгляд, специфичной особенностью могильников эпохи камня в бассейне Конды являются погребения, в которых отсутствуют либо останки усопших, либо сопроводительный инвентарь, или то и другое вместе. По нашим наблюдениям, эти вариации не связаны с погребальными традициями. Физико-химические свойства таежной почвы не способствуют столь длительному (более 8000 лет) сохранению останков погребенных и вещей из органики (кости, рога, дерева и т.п.). Следовательно, в идентификации захоронений каменного века таежных территорий севера Западной Сибири следует учитывать положение могильных ям в культурном ландшафте (планировка могильника), стандарт их формы и размеров, и - непременное условие - наличие охры (реже угля). Подобную систему распознавания погребений эпохи мезолита/неолита при отсутствии останков и вещей, а именно наличие охры в заполнении ям, можно наблюдать на территории Северной Европы [15]. Отсутствие вещей еще не означает их полного отсутствия при погребении усопшего; при благоприятной совокупности почвенных условий предметы из кости, рога, зубов животных сохраняются $[16$, c. $15-16 ; 17 ; 18$, c. 252$]$.

Таежное население бассейна Конды предавало умерших сородичей земле. Практиковалась ингумация и кремация с последующим захоронением сожженных костей. На могильниках захоронения проводились в соответствии с рядным принципом расположения ям в границах погребального поля. Основой могильных сооружений являлись ямы, размеры и пропорции которых, по-видимому, были индивидуальны и приближены к параметрам тела, уложенного в горизонтальном положении. Не исключено, что в ямах сооружали какие-то конструкции: зафиксированы канавки по периметру дна, уголь в заполнении; наличие ярусных захоронений указывает о возведении разделяющих перекрытий. Ориентировка ям относительно сторон света вариативна, преобладает С3-ЮВ. Обычно перед помещением в могильную яму тела усопших обворачивали или пеленали. Тело лежало в выпрямленной позе с вытянутыми вдоль туловища руками. Видимо, на этапе пеленания или до него тело обильно посыпали охрой. Превалируют одиночные погребения с горизонтальным положением тела. Особым видом в эпоху мезолита являются вертикальные погребения в округлых ямах. Кремированные останки захоранивали в могилах с охрой. Сожженные кости помещали по центру ям, их расположение обычно компактное. Одиночные захоронения осуществлялись на территории заброшенных поселений рядом с котлованами жилых построек или внутри них.

Погребальный инвентарь разнообразен по составу, умерших сопровождали каменные изделия - орудия и заготовки для них, индивидуальные украшения, фрагменты посуды, погребальная пища. Вещи были специально подготовлены для захоронения: подновлены лезвия каменных тесел, подретушированы грани наконечника, сломана глиняная посуда. Имело место особое отношение к черепам умерших.

В мезолите и неолите формировались те устойчивые черты погребальной практики таежного населения бассейна Конды, которые (с определенными ва- риациями) мы фиксируем и в эпоху бронзы, и в раннем железе, и в позднем средневековье. Для эпохи камня в период раннего голоцена различия в большей мере касаются облика погребального инвентаря. Мезолитические кремации Сатыги XVIa отличаются от кремаций раннего неолита Большой Умытьи 100 присутствием в захоронении вкладышевых орудий, а датированное энеолитом погребение на поселении Леуши XIV от неолитических могил на Большой Умытье 100 - шлифованным наконечником стрелы с шипами и фрагментом керамики с печатно-гребенчатым орнаментом [2, с. 34]. Возможно, что по мере накопления источников черты, выглядящие сегодня особенными, перейдут в разряд общих - например, неполное сожжение тел, завернутых в бересту, осуществленное непосредственно в могильных ямах, на могильнике Лева VIII эпохи раннего металла [3, с. 154].

Основные черты погребальной практики населения Конды мезолита/неолита эпохальны и зафиксированы на обширной территории лесной зоны Северной Евразии. Например, могилы, прорезающие котлованы ранних сооружений, изучены на стоянке Сосновый остров [19, с. 165-167] и поселении Мергень 7 [20, с. 72-74], захоронения внутри жилища на поселении Мергень 6 [21, с. 47-48], рядом с постройкой - на поселении Аятское II [22]. По мнению исследователей, погребения в жилищах могли являться строительной жертвой, и их следует рассматривать в контексте поселенческой, а не погребальной обрядности [22, с. 50-51]. Традиция обустройства небольших некрополей на площадке поселений или вблизи нее характерна для льяловского погребального обряда [18, с. 251]. Обряд кремации в погребальной практике населения Европейской части Евразии существовал с эпохи мезолита [23, p. 14-15]. Исследователями отмечено небольшое число кремированных захоронений по сравнению с ингумациями, а также наличие биритуальных могильников [23, p. 15]. Существует мнение, что погребения по обряду кремации совершались в исключительных случаях [24, с. 91]. Размещение усопшего в могиле в вертикальном положении - явление редкое. Такие захоронения, помимо Большой Умытьи 100, изучены на Оленеостровском могильнике $[17$, с. 31$]$, в Гросс Фреденвальде [25, p. 138-144], у села Пеган [16] и на могильнике Заречное-1 [26, с. 23-24]. Рядная/линейно-рядная планировка некрополей, использование охры, ингумация и пеленание тел зафиксированы на могильниках VIII-VI тыс. до н.э. Европейской части Евразии [27; 17; 18, с. 252].

\section{Список литературы:}

1. Беспрозванный Е.М., Погодин А.А. К вопросу о культовых представлениях мезолитического населения бассейна р. Конды // Вопросы археологии Урала: сб. науч. тр. Вып. 23 / отв. ред. Ю.Б. Сериков, Екатеринбург, 1998. С. 48-62.

2. Беспрозванный Е.М., Старостина Е.Е. Погребение в Нижнем Прииртышье // Проблемы урало-сибирской археологии: сб. науч. тр. / отв. ред. В.Т. Ковалева, Свердловск: УрГУ, 1986. С. 33-38.

3. Кокшаров С.Ф. Памятники энеолита севера Западной Сибири. Екатеринбург: Изд-во НПМП «Волот», 2009. $272 \mathrm{c}$.

4. Цеменков А.Е. Отчет о научно-исследовательской работе по теме: «Проведение археологических 
раскопок на поселении Большая Умытья 2 (Советский район, Западно-Даниловское месторождение)». Екатеринбург, 2010 // Архив АУ ХМАО - Югры «Центр охраны культурного наследия». Инв. № 6185, Д. $1285 \mathrm{a}$.

5. Погодин А.А. Отчет о научно-исследовательской работе по теме: «Изучение и обследование современного состояния археологических объектов в Советском районе Ханты-Мансийского автономного округа-Югры. Аварийные раскопки поселения Большая Умытья 8 в Советском районе Ханты-Мансийского автономного округа - Югры в 2009 году». Екатеринбург. 2010 // Архив АУ ХМАО - Югры «Центр охраны культурного наследия». Инв. № 6270. Д. 1362а.

6. Погодин А.А. Отчет о научно-исследовательской работе по теме: «Изучение и обследование современного состояния археологических объектов в Советском районе Ханты-Мансийского автономного округа - Югры. Аварийные раскопки поселения Большая Умытья 8 в Советском районе Ханты-Мансийского автономного округа - Югры в 2010 году». Екатеринбург. 2011 // Электронный архив АУ ХМАО Югры «Центр охраны культурного наследия». Диск 828.

7. Погодин А.А. Поселение Большая Умытья 9: результаты полевых исследований 2007-2008 гг. в Советском районе ХМАО - Югры // Ханты-Мансийский автономный округ в зеркале прошлого: сб. науч. статей. Вып. 8 / отв. ред. Я.А. Яковлев. Томск - Ханты-Мансийск: Изд-во Том. ун-та, 2010. С. 146-183.

8. Погодин А.А. Проведение спасательных археологических работ на участке строительства объектов ТПП «Урайнефтегаз» в границах территории выявленного объекта археологического наследия «Поселение Большая Умытья 100» в Советском районе Ханты-Мансийского автономного округа - Югры в 2012 году: Отчет о НИР: в 3-х книгах. Екатеринбург. 2014 // Архив АУ ХМАО - Югры «Центр охраны культурного наследия». Инв. № 8411. Д. 2280.

9. Погодин А.А. Погребальный обряд мезонеолитического населения севера Западной Сибири // Труды IV (XX) всерос. археол. съезда в Казани. T. I / ред. А.Г. Ситдиков, Н.А. Макаров, А.П. Деревянко. Казань: Отечество, 2014. С. 334-336.

10. Погодин А.А., Труфанов А.Я. Спасательные работы на городище Неушья 2.1 // Археологические открытия. 2016 год. М.: Институт археологии РАН, 2018. С. 372-374.

11. Погодин А.А. Отчет о НИР Спасательные археологические работы (раскопки) на выявленном объекте археологического наследия «Поселение Мулымья 3» на территории Убинского месторождения в Кондинском районе ХМАО - Югры в 2019 году. Екатеринбург, 2019.

12. Беспрозванный Е.М. Отчет о раскопках поселения Леуши IX в 1986 году // Архив ИА РАН.Р-1. № 11756 .

13. Беспрозванный Е.М. Мезолит таежной зоны Западной Сибири (предварительные итоги изучения) // Охранные археологические исследования на Среднем Урале: сб. науч. статей. Екатеринбург: Банк культурной информации, 1999. С. 26-38.

14. Клементьева Т.Ю., Погодин А.А. Технология орнаментации посуды позднего неолита поселения
Большая Умытья 100 // Археология и история Северо-Западной Сибири: сб. науч. ст. / отв. ред. А.Я. Труфанов. Нефтеюганск - Екатеринбург: ОАО «ИПП «Уральский рабочий», 2017. С. 20-49.

15. Ahola M.E. Tracing Neolithic Funerary Practices from Finnish Ochre Graves - a Case Study from Kukkarkoski Comb Ware Burial Ground // Thanatos. 2015. Vol. 4 (2). P. 23-40.

16. Сальников К.В. К вопросу о неолите степного Зауралья // Краткие сообщения института археологии. Вып. XLVII / отв. ред. А.Д. Удальцов. М.: Издво АН СССР, 1952. С. 15-23.

17. Гурина Н.Н. Оленеостровский могильник // Материалы и исследования по археологии СССР. Вып. 47 / отв. ред. А.Я. Брюсов. М., Л.: Изд-во АН CCCP, 1956. $431 \mathrm{c}$.

18. Костылева Е.Л., Уткин А.В. Нео-энеолитические могильники Верхнего Поволжья и ВолгоОкского Междуречья: Планиграфические и хронологические структуры. М.: ТАУС, 2010. 300 с.

19. Викторова В.Д. Сосновый остров - стоянка эпохи неолита и бронзы Среднего Зауралья // Советская археология. 1968. № 4. С. 161-173.

20. Еньшин Д.Н., Скочина С.Н., Слепченко С.М. Неолитические погребения в поселенческих комплексах на оз. Мергень // IV Северный археологический конгресс: материалы. 19-23 октября 2015 г., г. Ханты-Мансийск / отв. ред. Н.М. Чаиркина. Екатеринбург: ООО Универсальная Типография «Альфа Принт», 2015. С. 72-74.

21. Еньшин Д.Н., Скочина С.Н., Зах В.А. К вопросу о поселенческой обрядности в неолите Нижнего Приишимья (по материалам поселения Мергень 6) // Вопросы археологии, антропологии и этнографии. 2012. № 4 (19), C. 43-52.

22. Берс Е.М. Поздненеолитическое погребение на р. Аять // Советская археология. 1976. № 4. С. 190-200.

23. Grünberg J.M. Mesolithic burials - Rites, symbols and social organization of early postglacial communities // Mesolithic burials - Rites, symbols and social organization of early postglacial communities: International Conference Halle (Saale), Germany, $18^{\text {th }}-21^{\text {st }}$ September 2013. Halle, 2016. P. 13-24.

24. Добровольская М.В. К методике изучения материалов кремации // Краткие сообщения института археологии. Вып. 224 / Гл. ред. Н.А. Макаров. М.: Языки славянской культуры, 2010. С. 86-97.

25. Terberger T., Kotula A., Lorenz S., Schult M., Burger J., Jungklaus B. Standing upright to all eternity The Mesolithic burial site at Groß Fredenwalde, Brandenburg (NE Germany) // Quartär. 2015. Vol. 62. P. 133-153.

26. Зах В.А. Погребения эпохи неолита - ранней бронзы могильника Заречное-1 // Западная Сибирь в древности и средневековье: сб. науч. тр. / отв. ред. Р.С. Василевский. Тюмень: Тюменский гос. ун-т, 1985. C. 23-29.

27. Zagorska I. Mesolithic burial traditions in Latvia. A case study from Zvejnieki burial ground // Mesolithic burials - Rites, symbols and social organization of early postglacial communities: International Conference Halle (Saale), Germany, $18^{\text {th }}-21^{\text {st }}$ September 2013. Halle, 2016. P. 229-238. 


\title{
BURIAL PRACTICES OF THE POPULATION FROM THE KONDA RIVER BASIN IN THE MESOLITHIC AND NEOLITHIC PERIODS
}

(C) 2020

\author{
Klementyeva Tatyana Yuryevna, researcher; specialist-archaeologist \\ Institute of History and Archaeology of Ural Branch of Russian Academy of Sciences \\ (Yekaterinburg, Russian Federation); Research and Analytical Center of Problems of Preservation \\ of Cultural and Natural Heritage "AV KOM - Nasledie» (Yekaterinburg, Russian Federation) \\ Pogodin Andrey Albertovich, deputy general director for research \\ Research and Analytical Center of Problems of Preservation of Cultural and Natural Heritage \\ «AV KOM - Nasledie» (Yekaterinburg, Russian Federation)
}

\begin{abstract}
The paper is dedicated to burial practices of the Stone Age population that inhabited the territory of the North-West Siberia. The source base is represented by 14 complexes. The burial grounds and solitary graves are located on high slopes in the terrace conifer forest areas along the tributaries of the Konda River. The Mesolithic burials date back to the period starting from the $9^{\text {th }}-8^{\text {th }}$ millennium $\mathrm{BC}$ through the end of the $7^{\text {th }}$ millennium BC, while the Neolithic can be traced starting from the $7^{\text {th }}-6^{\text {th }}$ millennium BC to the middle of the $4^{\text {th }}$ millennium BC. The taiga hunters traditionally buried their deceased relatives in the ground. The burials tend to be clustered into linear groupings within the cemetery area. Solitary graves are found on the territory of apparently abandoned settlements near the foundation pits of houses or inside them. Two forms of burial were practiced: inhumation and cremation followed by the burial of burnt remains. Generally, the dead were buried in the extended position, i.e., lying flat with arms and legs straight. The bodies were covered with red ocher, wrapped or swaddled, and put into graves. A special type of Mesolithic burials was «vertical» burials, i.e., the dead were placed into a vertical shaft like pits. The cremated remains were buried in ocher graves. The burned bones were placed in the center of each pit. Solitary burials prevailed. Less common were paired and multi-tire graves. Children were buried in the same way as adults, the age range of the dead varied from 5-7 to 60 years. The deceased were buried together with stone tools, jewelry, fragments of dishes, funeral and memorial food. The burial things were «prepared» following a special ritual - the blades of stone adzes were sharpened, the pottery was broken. There are signs of special respect to the skulls of the dead. The traditional burial practices of the taiga population from the Konda River Basin remained the same throughout the Stone Age.

Keywords: burial practices; Mesolithic; Neolithic; Western Siberia; Konda River Basin; burial grounds; burials in settlements; inhumation; cremation; vertical burials; ocher; swaddling; burial equipment; skull burial; ceramics; stone tools; bone pendants; resin beads; Shoushma type; radiocarbon dating.
\end{abstract}

\section{ПОЯСНЫЕ ПРЯЖКИ РАННЕСАРМАТСКОГО ВРЕМЕНИ ТУРГАЯ}

(C) 2020

Сеитов Абай Мейрамович, научный сотрудник отдела первобытной археологии; научный сотрудник лаборатории археологических исследований

Институт археологии им. А.Х. Маргулана (2. Алматы, Республика Казахстан); Костанайский государственный университет им. А. Байтурсынова (2. Костанай, Республика Казахстан)

Аннотация. Статья посвящена поясным пряжкам раннесарматского времени Тургая. Тургайский прогиб это обширная территория, расположенная в северо-западной части Казахстана. Тургайский прогиб на севере переходит в Западно-Сибирскую низменность, на юге - в Туранскую. На западе прогиб соприкасается с Зауральским плато, а на востоке - с Казахским мелкосопочником. В статье анализируются три пряжки, происходящие из погребения № 5А кургана 1 могильника Каратомар и кургана 1 курганной группы Кеныш 3, рассматривается культурно-хронологическая позиция поясных пряжек Тургая в контексте распространения подобных изделий поясной гарнитуры в степях Евразии. Также затронута проблема происхождения и хронологии этих предметов. Пряжки, подобные каратомарской, пока обнаружены только на территории от Средней Азии и Казахстана до Нижнего Поволжья. Пряжка из кургана Кеныш 3 находит аналогии от Волго-Донья до Северного Китая. Типы пряжек, подобные тургайским, бытовали во II-I вв. до н.э. Анализируемые пряжки следует рассматривать в контексте общей моды на ношение поясной гарнитуры из металла, кости и камня, связанной с военной активностью хуннов.

Ключевые слова: Степи Евразии; Северо-Западный Казахстан; Тургай; Тургайский прогиб; могильник Каратомар; курганная группа Кеныш 3; раннесарматское время; раннесарматская культура; сарматы; хунны; поясные пряжки; II-I вв. до н.э.; пантера; верблюд; гагат; глинистый сланец.

\section{Введение}

Тургайский прогиб расположен в северо-западной части Казахстана, на территории Костанайской обл. На севере Тургай соприкасается с Западно-Сибирской низменностью, на юге переходит в ТуранСамарский научный вестник. 2020. Т. 9, № 1 (30) скую низменность. На западе он ограничен Зауральским плато, а восточная часть является западной окраиной Казахского мелкосопочника [1, с. 18-25]. Эпоха ранних кочевников Тургая мало изучена, поэтому актуально исследование скифо-сарматских 